\title{
A comparison of Goshawk summer diet in three areas with different breeding density in western Norway
}

\author{
Turid Verdal \& Vidar Selås
}

\begin{abstract}
Verdal, T. \& Selås, V. 2010. A comparison of Goshawk summer diet in three areas with different breeding density in western Norway. - Ornis Norvegica 33: 110-117.

In Norway, Goshawk Accipiter gentilis populations have declined in continuously forested areas in the inland, possibly because of decreased populations of grouse. The highest breeding densities are now found in landscapes dominated by farmland and urban areas, and in some areas close to the coast. In western Norway, we have compared the summer diet of Goshawks breeding at high densities in one island area and one urban area with that of Goshawks breeding at lower densities in an inland area at higher altitudes, approximately $90 \mathrm{~km}$ from the coast. Birds dominated the diet in all areas, but the diet diversity was lower in the inland than in the two other areas. The number of pigeons, Woodcock Scolopax rusticola and ducks/waders found at nest sites decreased with altitude, whereas the number of grouse increased. We conclude that Goshawks in the inland are more dependent on grouse because of lower availability of alternative prey.
\end{abstract}

Key words: altitude, coast, diet, Goshawk, grouse, Norway

Turid Verdal and Vidar Selås (correspondence), Department of Ecology and Natural Resource Management, Norwegian University of Life Sciences, P.O.Box 5003,NO-1432 Ås, Norway.E-mail: t_verdal@hotmail.com. vidar.selas@umb.no.

\section{INTRODUCTION}

The Goshawk Accipiter gentilis is a mediumsized raptor well adapted for hunting large bird prey in mature forests (Kenward 2006). In boreal forests in Fennoscandia, where grouse have been important prey (Hagen 1952, Sulkava 1964, Lindén \& Wikman 1983, Widén 1987, Tornberg 1997), there has been a long-term decline in Goshawk populations, probably because intensified forest management has led to reductions in preferred hunting habitats and prey numbers (Widén 1997, Tornberg et al. 2006). The decline has been less severe in areas with a strong influence of farmland and urban areas (Grønlien 2004, Selås et al. 2008). However, in Norway, the highest densities are presently found in some coastal areas in western and central parts of the country (Bergo 1992, Overvoll 1994, Sandvik 1996, Steinsvåg 2002, Grønlien 2004).

Most Goshawk males stay in their territories in winter (Widén 1985), and prey availability in late winter has been regarded as the most important factor for territory sizes and thus breeding densities (Newton 1979, Widén 1997, Kenward et al. 1999, Kenward 2006). In Fennoscandia, forest grouse (Tetraonidae), Jay Garrulus glandarius and Red Squirrel Sciurus vulgaris could be expected to be the most important prey during winter in forests, and Magpie Pica pica, Hooded Crow Corvus cornix, Jackdaw C. monedula and 
Feral Pigeon Columba livia in mixed forestfarmland landscapes (Widén 1987, Tornberg \& Colpaert 2001). During the breeding season, the proportion of grouse in the diet has been highest in forest-dominated areas, whereas the proportion of corvids has been highest in forest-farmland areas (Grønnesby \& Nygård 2000, Johansen et al. 2007). Hence, differences in the availability of winter-resident prey have been reflected also in the summer diet, when larger samples can be obtained with less field effort.

In western Norway, the number of territorial Goshawk pairs has been estimated to 5.3 per $100 \mathrm{~km}^{2}$ productive forest in an inland area, which is a relatively high breeding density for a forest-dominated area, whereas the corresponding numbers for two coastal areas were 11.1 and 14.3, respectively (Overvoll 2004). The difference can hardly be explained solely by different forest management strategies. Previous studies on Goshawk diet indicate that grouse is important as prey only in the inland (Bergo 1992, Overvoll 1999), but because the studies have been carried out in different years and with varying field effort, the results are not directly comparable. The main objective of our study was to compare estimates of the summer diet of Goshawks in the three areas, by using a standardized diet analysis technique during one breeding season, and by controlling for the proportion of different habitat types in each Goshawk territory. Our hypothesis is that the higher breeding density of Goshawk in the two coastal areas reflects higher availability of alternative winter-resident prey, which has buffered the negative impact of forestry on grouse numbers.

\section{MATERIAL AND METHODS}

The study was carried out in Hordaland County, western Norway, in three areas where Goshawk breeding density has been investigated through systematic surveys since the early 1990s. One area is situated at the island of Bømlo, Stord and Fitjar municipalities $\left(59^{\circ} 73^{\prime}-59^{\circ} 96^{\prime} \mathrm{N}\right.$, $05^{\circ} 26^{\prime}-05^{\circ} 48^{\prime} \mathrm{E}, 0-200 \mathrm{~m}$ a.s.l., hereafter the island area), one in an urban coastal area in Os and Bergen municipalities $\left(60^{\circ} 22^{\prime}-60^{\circ} 25^{\prime} \mathrm{N}\right.$, $05^{\circ} 38^{\prime}-05^{\circ} 47^{\prime} \mathrm{E}, 100-200 \mathrm{~m}$ a.s.l., hereafter the urban area), and one in an inland area, in Voss municipality $\left(60^{\circ} 65^{\prime}-60^{\circ} 81^{\prime} \mathrm{N}, 06^{\circ} 48^{\prime}-06^{\circ} 70^{\prime} \mathrm{E}\right.$, 200-500 m a.s.l., hereafter the inland area), approximately $90 \mathrm{~km}$ from the coast. The two former (coastal) areas are characterized by mild winters (mean January temperatures 1960-1990: $1.9^{\circ} \mathrm{C}$ and $0.6^{\circ} \mathrm{C}$, respectively), whereas in the inland, winter temperatures are lower (mean January temperature $1960-1990:-4.6^{\circ} \mathrm{C}$ ).

In all areas there is a quite roughed topography. The island landscape consists of heath-lands, forests, bogs, small lakes, and some farmland and urban areas. The urban area has a higher proportion of urban areas, intermixed with forests, small lakes and farmland. The inland area is dominated by high-altitude bare rocks and low-productive forests, intermixed with bogs, farmland and urban areas. In all areas, Scots Pine Pinus sylvestris dominates the forests, albeit deciduous tree species are locally highly abundant in the two coastal areas. Norway Spruce Picea abies is the most replanted species in clear-cuts. In the late 1990s, older thinned stands and mature forest (development class IV and V) constituted approximately 61,73 and $58 \%$ of the productive forest areas in the island, urban and inland area, respectively.

We have collected prey remains from plucking posts near nests, a method that in general underestimates small prey (Sulkava 1964, Rutz 2003, Tornberg \& Reif 2007). However, the method should be suitable for comparing different regions in one particular year, as long as the field work is conducted by equal effort and by the same persons. Prey remains were collected from four nest sites in the island area, three in the urban area and four in the inland (Table 1). Each nest was visited seven times during May-July 2006. To avoid replication, remains from the same species collected at different plucking posts at the same day were compared and interpreted to be one or more individuals. A species found in pellets was counted only if not found also among other prey remains during that visit. 
We evaluated prey diversity by using Simpson's Reciprocal, and addressed diet similarity between areas by using Sorensen's coefficient of percent similarity (Smith \& Smith 2006). When comparing prey group composition between the three study areas, prey species were classified into seven classes, similar to those used by Johansen et al. (2007); thrushes, Jay, farmland corvids, pigeons, grouse, Red Squirrel and «other prey».

Because nest sites in the two coastal areas were situated at lower altitudes than inland nest sites (Table 1), we used both region (dummy variable) and altitude as explanatory variables (predictors) when comparing the occurrence of common prey species or groups of prey species at Goshawk nest sites in the inland (region 1) with that of the two coastal areas (region 2). Because of overdispersal in our count data, we used a generalized linear model with quasi-Poisson error distribution and a log link, weighted according to the total number of prey found at each nest site. The numbers of prey species or prey groups found at a nest site are ultimately proportions and therefore not independent. We therefore adjusted $\alpha$-levels by using Bonferroni correction.

To control for the possible impact of variations in habitat composition within Goshawk home ranges, we used the same method as Johansen et al. (2007), i.e. we made circles of $2 \mathrm{~km}$ radius (ca. $13 \mathrm{~km}^{2}$ ) around each nest location on GIS maps, where we mapped the percent of different habitat types (Table 1). Maps were obtained from the Norwegian Forest and Landscape Institute (http://www.skogoglandskap.no), and managed in ArcView GIS 3.3 (ESRI 2002). The habitats used as predictors in the statistical models were the percent of lakes and sea, and for the land area, the percent of urban areas, farmland, forests and other habitats (mainly heathlands, bogs and mountains). The proportion of lakes and sea correlated significantly with the proportion of other habitats $(\mathrm{r}=0.65, \mathrm{p}=0.032)$ and almost so with altitude $(\mathrm{r}=-0.52, \mathrm{p}=0.098)$, and was therefore used as predictor only for the occurrence of ducks and waders in the diet.

\section{RESULTS}

From prey remains collected at the 11 Goshawk nest sites, we identified 576 prey items, including 34 bird species and five mammal species (Appendix 1). The relative abundance of prey groups differed between the three areas $\left(\chi^{2}=164.9, \mathrm{df}=12\right.$, $\mathrm{p}<0.001$; Fig. 1). The diet diversity was higher in the island (SRI=29.3) and urban (SRI=30.0) area than in the inland (SRI=20.4). The diet similarity between the island and urban area was $66.1 \%$, between the island and the inland area $41.1 \%$ and between the urban and the inland area $44.5 \%$. Corvids and especially thrushes were common as prey in all study areas (Fig. 1).

In the quasi-Poisson regression models, altitude was a better predictor than region for most of the prey groups that differed in occurrence between the two coastal areas and the inland area (Fig. 1 ), except of the group other prey. However, the occurrence of the most common species in this group, the Woodcock Scolopax rusticola, as well as that of ducks and waders (exclusive Woodcock) pooled, was best explained by altitude. When including habitat in the models for pigeons and Woodcock, the occurrence of pigeons, Woodcock and ducks/waders decreased significantly with altitude, whereas that of grouse increased (Table 2), even by Bonferroni-correction (number of tests $=8, \alpha=0.0063$ ). Willow Grouse Lagopus lagopus and Capercaillie Tetrao urogallus were found as prey only in the inland, whereas Black Grouse Tetrao tetrix was found also in the two coastal areas. For ducks and waders, the occurrence was better explained by altitude $(\mathrm{p}=0.002$; Table 2) than by the proportion of lakes and sea $(\mathrm{p}=0.088)$.

Thrushes, Jay, farmland corvids and Red Squirrel did not show any relationships with region or altitude. The Fieldfare Turdus pilaris, which inhabit open habitats, was positively related to the proportion of farmland $(\mathrm{p}<0.001)$, whereas the occurrence of the remaining thrush species correlated positively with the proportion of urban areas $(p=0.005)$. For the forest-dwelling Jay, there 
Table 1. Information about habitat composition around Goshawk nests in the island (IS1-IS4), urban (UR5-UR7) and inland (IN8-IN11) study area in Western Norway, where prey remains were collected in summer 2006. The proportion of lakes and sea (of total area), and of urban areas, farmland, forest and other habitats (of total land area), refer to a circle with radius $2 \mathrm{~km}$ and the Goshawk nest in center.

\begin{tabular}{lcccccc}
\hline $\begin{array}{l}\text { Nest } \\
\text { number }\end{array}$ & $\begin{array}{c}\text { Altitude } \\
\text { m a.s.l. }\end{array}$ & $\begin{array}{c}\text { Lakes/sea } \\
\mathbf{\%}\end{array}$ & $\begin{array}{c}\text { Urban areas } \\
\mathbf{\%}\end{array}$ & $\begin{array}{c}\text { Farmland } \\
\boldsymbol{\%}\end{array}$ & $\begin{array}{c}\text { Forests } \\
\boldsymbol{\%}\end{array}$ & $\begin{array}{c}\text { Other } \\
\mathbf{\%}\end{array}$ \\
\hline & & & & & & \\
IS1 & 38 & 47.9 & 0 & 5.8 & 78.9 & 15.4 \\
IS2 & 60 & 13.6 & 0 & 3.7 & 81.6 & 14.7 \\
IS3 & 195 & 47.6 & 0 & 3.2 & 56.9 & 39.9 \\
IS4 & 20 & 31.0 & 0 & 4.3 & 58.0 & 37.7 \\
UR5 & 163 & 13.1 & 2.3 & 10.1 & 85.2 & 2.4 \\
UR6 & 122 & 7.7 & 1.7 & 8.1 & 89.9 & 0.2 \\
UR7 & 180 & 7.4 & 4.9 & 16.0 & 63.7 & 15.4 \\
IN8 & 250 & 0.0 & 0 & 24.2 & 72.0 & 3.8 \\
IN9 & 235 & 1.2 & 0 & 14.7 & 74.3 & 11.0 \\
IN10 & 483 & 8.2 & 0 & 10.0 & 78.6 & 11.3 \\
IN11 & 449 & 0.0 & 0 & 6.1 & 74.8 & 19.1 \\
\hline
\end{tabular}

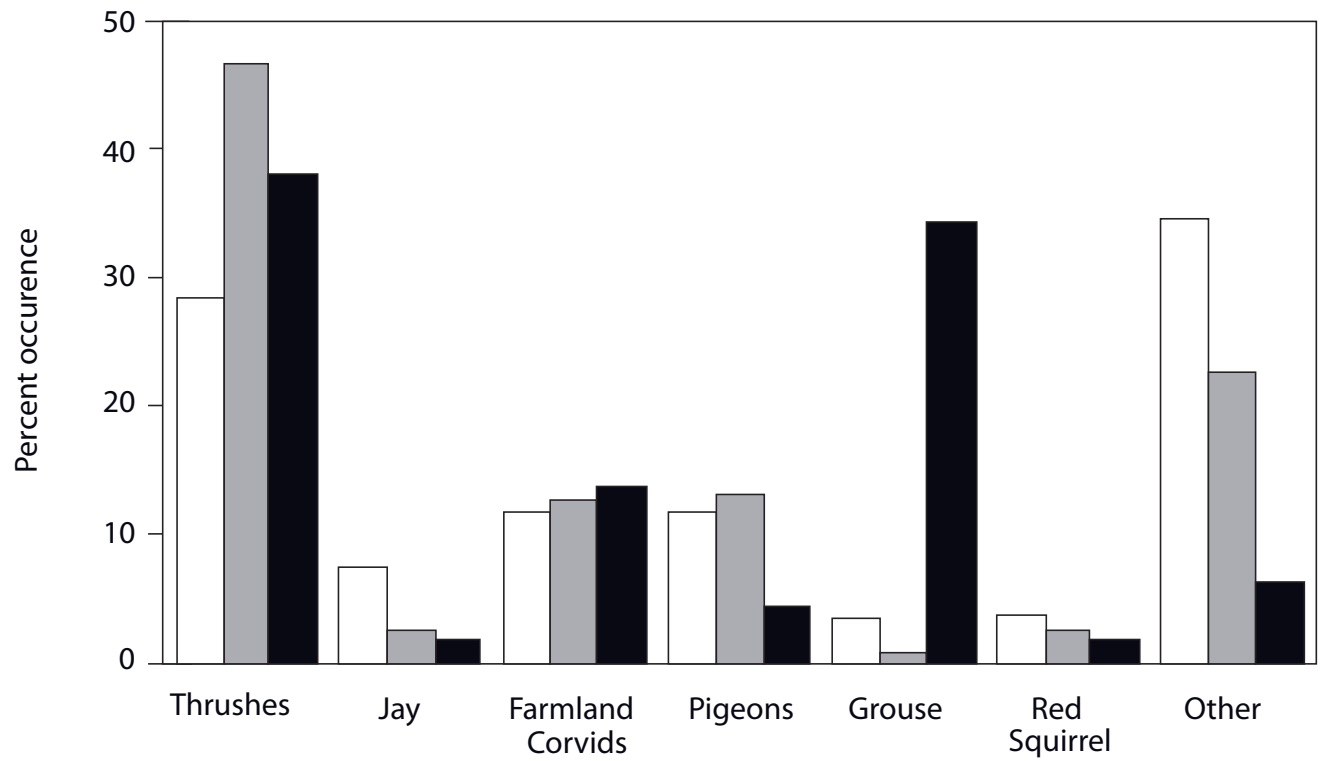

Figure 1. Proportion of different prey groups identified from prey remains at 11 Goshawk nests in Hordaland County, western Norway, 2006. White bars: island area; grey bars: urban area; black bars: inland area . 
Table 2. Results from weighted generalized linear models (quasi-Poisson error distribution and a log link) where the response variable is the number of prey found at Goshawk nests $(n=11)$ in Western Norway, weighted according to the total number of prey found at each nest. Predictors are the altitude at the nest site and the proportion of different habitat types within $2 \mathrm{~km}$ radius from the nest. Cumulative values are given for the proportion of the total deviance explained by the model (Dev. expl.).

\begin{tabular}{llccccc}
\hline \multirow{2}{*}{ Prey } & Variable & Estimate & SE & t-value & p & Dev.expl. \\
& & & & & & \\
Grouse & Intercept & -0.226 & 0.608 & & & \\
& Altitude & 0.007 & 0.002 & 4.67 & 0.0012 & 0.73 \\
\multirow{2}{*}{ Pigeons } & Intercept & -1.883 & 1.056 & & & \\
& Forest & 0.057 & 0.013 & 4.35 & 0.0025 & 0.44 \\
& Altitude & -0.005 & 0.001 & -3.70 & 0.0061 & 0.82 \\
\multirow{2}{*}{ Woodcock } & Intercept & 1.693 & 0.311 & & & 0.57 \\
& Other habitats & 0.040 & 0.009 & 4.54 & 0.0019 & 0.88 \\
& Altitude & -0.006 & 0.001 & -4.31 & 0.0026 & \\
\multirow{2}{*}{ Ducks/waders } & Intercept & 3.053 & 0.208 & & & 0.74 \\
& Altitude & -0.007 & 0.002 & -4.32 & 0.0019 & \\
\hline
\end{tabular}

was a negative relationship with the proportion of farmland and urban areas combined $(\mathrm{p}=0.019)$, whereas the Magpie, which is closely connected to human settlements, tended to be positively related to farmland and urban areas $(\mathrm{p}=0.088)$.

\section{DISCUSSION}

Most of the significant relationships between the occurrence of prey at Goshawk nests and habitat composition within $2 \mathrm{~km}$ from the nests were in accordance with the habitat preference of the prey species in question, suggesting that regional differences in Goshawk diet mainly reflected differences in prey abundance. Goshawk diet differed between the three areas, but the similarity between the island and urban area was relatively high. Diet diversity was higher here than in the inland. In western Norway, prey communities in coastal and urban landscapes are in general more diverse than in forested landscapes (Overvoll 1994, Sandvik 1996), probably due to both higher habitat diversity and higher land productivity (Norwegian Forest and Landscape Institute;
http://www.skogoglandskap.no).Prey groups that were related to region or altitude with regard to their occurrence at Goshawk nests were grouse, pigeons and «other prey».

The major difference between the areas was the high proportion of grouse, especially Willow Grouse, in the Goshawks' diet in the inland. Grouse populations often exhibit strong interannual variations in density (Angelstam et al. 1985, Ranta et al. 1995), but such variations are usually synchronized over large areas, and should thus be of less importance for the comparison of our relatively close study areas. Our result is also in accordance with the former studies; grouse constituted only $2.3 \%$ of 828 prey collected in the urban area during 1991-1996 and 3.0\% of 69 prey collected in the island area in 1995 (Overvoll 1999), whereas in the inland area, they made up $33.1 \%$ of 133 prey from 1984-1991 (Bergo 1992). In South Norway, there usually is a decline in grouse abundance along the altitude gradient from the coast to the inland, but it should also be taken into account that in our study, individual 
Goshawks had larger territories in the inland, and thus probably exploited grouse from larger areas than those breeding close to the coast.

The occurrence of pigeons, i.e. Feral Pigeon and Wood Pigeon, was negatively related to altitude and positively to the proportion of forest. Feral Pigeons are common only in urban areas in the lowland, but in western Norway, Goshawks also frequently kill domestic pigeons Columba livia domestica, and the correlation with forests may have been influenced by the location of homing pigeon lofts (Overvoll 1994). In accordance with the study of Overvoll (1999), we found that the Woodcock was most important as prey in the island area. The negative relationship with altitude probably reflects the impact of land productivity. The Woodcock depends on earthworms (van Gils \& Wiersma 1996), which are most common in moist and high-productive deciduous forests. Land productivity may also explain why the occurrence of other waders and ducks in the diet was better explained by altitude than by the proportion of lakes and sea.

Thrushes constituted a large proportion of Goshawk prey numbers, and their occurrence did not differ between the areas. Their importance is in accordance with results from video recordings at Goshawk nests in other regions of Norway (Grønnesby \& Nygård 2000, Johansen et al. 2007). Although their contribution will be less with regard to biomass, they appear to make up a significant proportion of Goshawk food in Norway in summer. Neither did the occurrence of corvids, which in contrast to thrushes are present throughout the year, differ between the study areas.

Our study supports the hypothesis that the high breeding densities of Goshawk in our coastal study areas, where grouse densities are low, can be explained by higher availability of alternative winter-resident prey species, which may have buffered negative effects of forestry and declining grouse numbers. These prey species are probably favoured by the general higher land productivity, and/or by higher habitat diversity. Besides, due to the mild climate in the coastal areas, individuals of Wood Pigeon (Feral Pigeons are winter-resident), Woodcock and ducks may stay throughout the winter (Falkenberg 1999, 2000, 2003, Steinsvåg \& Overvoll 2003, 2004, 2005 ), in contrast to the situation in the inland, where Goshawks have few alternatives to grouse hunting during winter.

\section{ACKNOWLEDGEMENTS}

We are grateful to Magnus J. Steinsvåg, Olav Overvoll and Gunnar Bergo for assistance in the field. The study was founded by the Norwegian Directorate for Nature Management and the National Environmental Authorities in Hordaland County.

\section{SAMMENDRAG}

En sammenligning av hønsehaukens næringsvalg i tre områder med ulik hekketetthet på Vestlandet

Hønsehauken Accipiter gentilis har vist en generell bestandsnedgang i skogslandskap i Norge, sannsynligvis i første rekke som følge av en nedgang $\mathrm{i}$ bestandene av hønsefugler. Tettest hekkebestand av hønsehauk finner vi nå i jordbrukslandskap og urbane områder, samt i enkelte kystnære områder. Vi har sammenlignet næringsvalget hos hønsehauk i et kystøylandskap og i et kystnært urbant område på Vestlandet med næringsvalget i et område med lavere hekketetthet ca $90 \mathrm{~km}$ fra kysten (innland). Fugl dominerte dietten i alle områdene, men artsdiversiteten var lavere i innlandet. Antallet av rugde Scolopax rusticola og våtmarksfugler funnet ved hønsehaukreir var negativt relatert til reirets høyde over havet, mens det var en positiv korrelasjon for hønsefugler. Unders $\varnothing$ kelsen indikerer at hønsehauken er mer avhengig av hønsefugler i innlandet på grunn av lavere forekomst av alternative byttedyr. 


\section{REFERENCES}

Angelstam, P., Lindström, E. \& Widén, P. 1985. Synchronous short-term population fluctuations of some birds and mammals in Fennoscandia - occurrence and distribution. - Holarct.Ecol. 8: 285-298.

Bergo, G. 1992. Bestandsstørrelse, reirhabitat og reproduksjonsbiologi hjå hønsehauk. Rapport nr 5, Fylkesmannen i Hordaland, Miljøvernavdelinga: 1-31.

Environmental Systems Research Institute (ESRI) 2002. ArcView 3.3 GIS. Redlands, California.

Falkenberg, F. 1999. Fugler i Hordaland 1998. Krompen 28: 66-87.

Falkenberg, F. 2000. Fugler i Hordaland 1999. Krompen 29: 73-103.

Falkenberg, F. 2003. Fugler i Hordaland 2002. Krompen 32: 131-156.

van Gils, J. \& Wiersma, P. 1996. Eurasian Woodcock Scolopax rusticola. In Del Hoyo, J., Elliott, A and Sargatal, J. (eds.): Handbook of the birds of the world, vol. 3, Hoatzin to auks, 489. Barcelona, BirdLife International, Lynx Edicions.

Grønlien, H. (ed.) 2004. Honsehauken i Norge. Bestandens status og utvikling siste 150 år. NOF Rapportserie 5-2004.

Grønnesby, S. \& Nygård, T. 2000. Using time-laps video monitoring to study prey selection by breeding Goshawks Accipiter gentilis in Central Norway. - Ornis Fenn. 77: 117-129.

Hagen, Y. 1952. Rovfuglene og viltpleien. Gyldendal, Oslo.

Johansen, H.M., Selås, V., Fagerland, K.L., Johnsen, J.T., Sveen, B.-A., Tapia, L. \& Steen, R. 2007. Goshawk diet during the nestling period in farmland and forest-dominated areas in southern Norway. - Ornis Fenn. 84: 181-188. Kenward, R., 2006. The Goshawk. Poyser, London.

Kenward, R.E., Marcström, V. \& Karlbom, M. 1999. Demographic estimates from radio-tagging: models of age-specific survival and breeding in the Goshawk. - J. Anim. Ecol. 68: 1020-1033.

Lindén, H. \& Wikman, M. 1983. Goshawk Predation on Tetraonids - Availability of prey and diet of the predator in the breeding season.-J.Anim. Ecol. 52: 953-968.

Newton,I., 1979. Population ecology of raptors. Poyser, London.

Overvoll, O. 1994. Breeding ecology of Goshawks (Accipiter gentilis) in western Norway. Thesis Candidatus scientiarum. Department of Animal Ecology, Institute of Zoology, University of Bergen.

Overvoll, O. 1999. Litt om hønsehauken i Hordaland sitt val av næring i hekketida. - Krompen 2: 88-93.

Overvoll, O. 2004. Hordaland. Pp. 18-19 in Grønlien, H. (ed.) 2004: Hønsehauken i Norge.Bestandens status og utvikling siste $150 \mathrm{a}$. NOF Rapportserie 5-2004.

Ranta, E., Lindström, J. \& Lindén, H. 1995. Synchrony in tetraonid population dynamics. - J. Anim. Ecol. 64: 767-776.

Rutz, C. 2003. Assessing the breeding season diet of Goshawk Accipiter gentilis: biases of plucking analysis quantified by means of continuous radio-monitoring. - J. Zool. 259: 209-217.

Sandvik, J. 1996. Hønsehaukens status i Sør-Trøndelag. Pp 16-19 in: Nygård, T, Wiseth, B. (eds.). Hønsehauken i skogbrukslandskapet. NINA temahefte nr. 5.

Selås, V., Steen, O.F. \& Johnsen, J.T. 2008. Goshawk breeding densities in relation to old forest in south-eastern Norway. - For. Ecol. Manage. 256: 446-451.

Smith, R.L. \& Smith, T.M. 2006. Elements of Ecology. Sixth edition. Pearson Education Inc., Benjamin Cummings, San Francisco.

Steinsvåg, M.J. 2002. Kartlegging av hekkestadar for hønsehauk (Accipiter gentilis) $i$ B $\phi m l o ~ o g$ Sveio kommunar, Hordaland. Fylkesmannen i Hordaland, Miljøvernavdelinga. MVArapport 2:2002.

Steinsvåg, M.J. \& Overvoll, O. 2003. Viltet i Bфmlo. Kartlegging av viktige viltområde og status for viltartane. Bømlo kommune og fylkesmannen i Hordaland. MVA-rapport 4:2003.

Steinsvåg, M.J. \& Overvoll, O. 2004. Viltet $i$ Stord. Kartlegging av viktige viltområde og status for viltartane. Stord kommune og fylkesmannen i Hordaland. MVA-rapport 3:2004.

Steinsvåg, M.J. \& Overvoll, O. 2005. Viltet $i$ Bergen. Kartlegging av viktige viltområder og status for viltartene. Bergen kommune og fylkesmannen i Hordaland. MVA-rapport 2:2005.

Sulkava, S. 1964. Zur Nährungsbiologie des Habichts Accipiter gentilis. - Aquilo, Ser. Zoologica 3: 1-103.

Tornberg, R. 1997. Prey selection of the Goshawk Accipiter gentilis during the breeding season: the role of prey profitability and vulnerability. - Ornis Fenn. 74: 15-28.

Tornberg, R. \& Colpaert, A. 2001. Survival, ranging, habitat choice and diet of the Northern Goshawk Accipiter gentilis during winter in Northern Finland. - Ibis 143: 41-50.

Tornberg, R., Korpimäki, E. \& Byholm, P. 2006. Ecology of the northern goshawk in Fennoscandia. - Stud. Avian Biol. 31: 141-157.

Tornberg, R. \& Reif, V. 2007.Assessing the diet of birds of prey: a comparison of prey items found in nests and images. - Ornis Fenn. 84: 21-31.

Widén, P. 1985. Breeding and movements of goshawks in boreal forests in Sweden. - Holarct. Ecol. 8: 273-279.

Widén, P. 1987. Goshawk predation during winter, spring and summer in a boreal forest area of central Sweden. - Holarct. Ecol. 10: 104-109.

Widén, P. 1997. How, and why, is the Goshawk (Accipiter gentilis) affected by modern forest management in Fennoscandia? - J. Raptor Res. 31: 107-113. 
Appendix 1. Prey remains found at Goshawk nest sites in western Norway in 2006. Nest numbering as in Table 1.

\begin{tabular}{llllllllllll}
\hline Prey species & IS1 & IS2 & IS3 & IS4 & UR5 & UR6 & UR7 & IN8 & IN9 & IN10 & IN11
\end{tabular}

Anas platyrhynchos

Anas crecca

Indet. duck

Accipiter nisus

Accipiter gentilis

Tetrao urogallus

Tetrao tetrix

Lagopus lagopus

Vanellus vanellus

Haematopus ostralegus

Pluvialis apricaria

Scolopax rusticola

Gallinago gallinago

Actitis hypoleucos

Larus canus

Sterna hirundo

Columba palumbus

Columba livia

Dendrocopos major

Picus viridis

Anthus sp.

Erithacus rubecula

Turdus merula

Turdus pilaris

Turdus merula/pilaris

Turdus iliacus

Turdus philomelos

Phylloscopus trochilus

Parus major

Garrulus glandarius

Pica pica

Corvus cornix

Corvus monedula

Corvus corax

Sturnus vulgaris

Loxia pytyopsittacus

Plectrophenax nivalis

Indet. bird

Microtus agrestis

Rattus norvegicus

Sciurus vulgaris

Lepus timidus

Mustela nivalis

$\begin{array}{lllll}- & 2 & - & - & 1\end{array}$

Total

48

73

53

68

40

51

78

65

19

58 